\title{
Analysis of Correlation Between Indonesian Composite Index and Economic Growth in Indonesia
}

\author{
Poppy Camenia Jamil M. Irfan Rosyadi Ade Widowati \\ Faculty of Economics, Riau Islamic University, \\ Kaharuddin Nasution Street No. 113. Pekanbaru Riau Indonesia
}

\begin{abstract}
This study aims to analyze the correlation between the Indonesia Composite Index (ICI) and Economic Growth in Indonesia. This study uses time series data for the period $2001-2018$, the secondary data have been obtained from the Indonesian Central Statistics Agency and Bank Indonesia (BI). The data analysis method uses "Two stage lest square simultaneous equation model" to explain the reciprocal correclation between the Indonesian Composite Index (ICI) and economic growth, Gross Domestic Product (GDP) in Indonesia. The analysis shows that both variables have a positive and significant feedback effect in the long term.
\end{abstract}

Keywords: Indonesia Composite Index, Economic Growth, Two stage lest square

DOI: $10.7176 / \mathrm{EJBM} / 12-8-07$

Publication date:March $31^{\text {st }} 2020$

\section{Introduction}

Economic growth has an important development role to be a main indicator in assessing the welfare of a country. Sukirno (2004) has stated that good economic development can increase the prosperity and welfare of the community and also increase opportunities for new jobs for the community. Basically, a country's economic growth is an achievement of the country's economic development. A factor that influences economic growth such as capital and rapid development of technology is one of the investment attractiveness for investors which will certainly have an impact on the economy. Current economic activities not only manage available resources but also expand them to produce greater profits. The role of investors in the development of innovation, in accordance with the theory of economic growth proposed by Schumpeter in Sukirno (2004), is important in economic growth. According to Todaro (2000), investment drives the life of the nation's economy as capital formation increases production capacity, increases national income and creates new jobs. One of the investment activities in a country can be seen through a capital market activity. A good response to investment in the capital market is reflected through a significant rate of return on investment. This signal attracts more investors and will certainly expand the scope of economic activity which will ultimately increase economic growth. Generally, a signal in the capital market can be reflected through stock index in the capital market. A change in the value of stock index reflects investor interest in a country. Indonesia has several capital market indices that are divided by an industry sector and a combination of all sectors, known as the ICI (Indonesian Composite Index).

Boubakari and Jin (2010), Ishioro (2013), and Ngare et all (2014) explained that economic growth and capital market have a correlation. Pan and Mishra (2018) found that economic growth leads to the formation of a capital market condition, in line with the hypothesis stated by Friedman and Schwartz (1963) in Sukirno (2004). Research conducted by Duca (2007) concerning the correlation between capital market and economic growth has stated that a sizeable decline in the capital market will also have an impact on economic activity. Nieuwerburgh, Buelens, and Cuyvers (2006) have stated that a change in the capital market react to GDP for a long term period but not in the short term.

Good economic growth in a country will attract an investor to invest in the capital market and will affect the overall value of the shares due to an increased company-profit. A good market condition will affect the economy since with capital an operational activity and innovation development of company can be better so that the profit increases and stock prices raises and it will ultimately affect stock returns. Sukumar (2017) has stated that the capital market plays a role in promoting economic development, although there is no standard mapping of the correlation between the two. Based on this explanation, it is necessary to conduct more in-depth research to explain the correlation between the Stock Market represented by the Indonesian Composite Index and Economic Growth in Indonesia.

\section{Literature Review}

\subsection{Economic Growth}

Measurement of economic growth is explained by national income. Economic growth is a prerequisite for an increase in the welfare of a nation (Irawan \& Suparmoko, 2002). The goal of economic growth is to achieve a higher level of prosperity. Economic growth is defined as a process of increasing per capita output in the long run (Boediono, 1985). All countries in the world have agreed that to measure the economic welfare of a nation, the indicator used is the value of gross product per capita. The higher the gross product per capita is, the more 
prosperous the country is.

\subsection{Foreign Investment}

According to Kairupan (2013), foreign investment is a strategic source of foreign funding to support national development, especially in the development of the real sector which is expected to have an impact on broad jobs. The importance of foreign investment role in Indonesia's economic development is also reflected in Law No. 25 of 2007 concerning Investment - a positive legal basis for investment activities in Indonesia. Law on investment article 3 paragraph 2 states the purposes of conducting an investment are as follows (1) Increasing national economic growth, (2) Creating employment opportunities, (3) Increasing sustainable economic development, (4) Increasing the competitiveness of the national business, (5) Increasing the capacity and capability of national technology, (6) Encouraging the development of social economy, (7) Processing the potential economy into a real economic power by using funds from both domestic and foreign sources, and (8) Improving community welfare. Increasing foreign investment in Indonesia does not come by itself, but it requires hard work to be able to create conducive investment climate. One of the very significant classic issues in creating conducive investment climate in Indonesia is the problem of law enforcement, limited infrastructure, security, and social and political stability. According to Rudolf Dolzer and Christoph Schreurer (2008) direct investment is often interpreted as an investment activity that involves the transfer of funds, long-term projects, the purpose of earning regular income, the participation of the person transferring the funds, and business risk.

The investment law article 1 number (3) states that foreign investment is an investment activity to conduct business in the territory of the Republic of Indonesia carried out by foreign investors, both those who use foreign capital fully or those who are affiliated with domestic investors. Based on the description above, it is clear that foreign investment is not only the capital that comes from abroad but can also be a joint venture, in which there is a merger between capital originating from foreign and domestic sources.

\subsection{Capital Market and Economic Growth}

An investment activity in a country can be seen through a capital market activity. The capital market is a place for an investor to invest in an interested industrial sector. The fund collected in the capital market is used to develop the company's economic activities which will also affect the country's economic activities. A good response to investments in the capital market is reflected through a significant rate of return on investment. This signal attracts more investors and will certainly expand the scope of economic activity which will ultimately increase economic growth. Generally, a signal in the capital market can be reflected through stock index in the capital market. A change in the index value illustrates the condition of investors' investment interest in the country.

Boubakari and Jin (2010), Ishioro (2013), and Ngare et all (2014) stated Economic growth and capital market have a correlation while Pan and Mishra (2018) stated that in China it is found a negative long-term correlation between the stock market and economic growth - economic growth leads to the formation of a capital market condition -, but Ritter (2005) stated the correlation between stock market and economic growth is not always found.

Duca (2007) - the correlation between the capital market and economic growth - stated that the decline in the capital market has an impact on the decline in economic activity. Duca's hypothesis (2007) was formed based on research that refers to Tobin (1969), namely that the increasing of a company value will increase production capacity which has an impact on the economy. Second, Modigliani (1989) stated that the heights of stable and permanent income will increase the amount of consumption. Third, Bernanke and Gertler (1989) stated the financial market as an accelerator which signals an economic condition. Fourth, Humpe and Macmillan (2005) stated an increase in production will trigger an increase in the stock market. Then, Schwert (1989) stated the volatility that occurs in the market depends on an economic condition.

Nieuwerburgh, Buelens, and Cuyvers (2006) stated that a change in the capital market reacts to GDP for a long term period but not in the short term. Jamil and Kurniawati (2018) in a study of correlation between the capital market and economic growth using an Error Correction Model (ECM) stated that there is a long-term correlation between the capital market and economic growth.

\section{Methodology}

This research uses a quantitative method with secondary data - data collected from a data provider institution or a second party as a data source, in this case, namely Bank Indonesia and the Central Statistics Agency. The data are in the form of Time series - data collected based on a certain time span - from 2001 to 2018. The data used are the Gross Domestic Product (GDP) of Indonesia in percent (\%), Indonesian Composite Index (ICI) of Indonesia in index, and Foreign Investment (FI) in Indonesia in Rupiah (Rp).

\subsection{Two Stage Least Square Method}

The Two Stage Least Square (TSLS) method is a simultaneous equation model commonly used to estimate two- 
way correlation that is interrelated between the variables; i.e in simultaneous model there is an equation that uses an independent variable and a dependent variable. In an equation, a variable can be an independent variable, but at the same time the variable becomes the dependent variable (Widarjono, 2013). In this case, it is used to analyze the correlation between GDP, ICI and FI.

\section{Discussion}

4.1 The result of Two Stage Least Square Method

The data processing results using the Two Stage Least Square (TSLS) Model are as follows:

1. The effect of FI and ICI on GDP $G D P_{t}=\beta_{1}+\beta_{2} F I_{t}+\beta_{3} I C I_{t}+e_{t}$

Table 4.1 First result of Two Stage Least Square

\begin{tabular}{|c|c|c|c|c|}
\hline \multicolumn{5}{|c|}{ Dependent Variable: GDP } \\
\hline \multicolumn{5}{|c|}{ Method: Panel Two-Stage Least Squares } \\
\hline Variable & Coefficient & Std. Error & t-Statistic & Prob. \\
\hline ICI & 4.690 .190 & 4.351 .009 & 1.077 .955 & 0.0000 \\
\hline FI & -6.358 .080 & 3.182 .019 & -1.998 .127 & 0.0505 \\
\hline $\mathrm{C}$ & -272490.0 & 139617.1 & -1.951 .695 & 0.0559 \\
\hline R-squared & 0.712344 & \multicolumn{2}{|c|}{ Mean dependent var } & 1149475 . \\
\hline Adjusted R-squared & 0.702251 & \multicolumn{2}{|c|}{ S.D. dependent var } & 876582.5 \\
\hline S.E. of regression & 478319.1 & \multicolumn{2}{|c|}{ Sum squared resid } & $1.30 \mathrm{E}+13$ \\
\hline F-statistic & 7.057 .684 & \multicolumn{2}{|c|}{ Durbin-Watson stat } & 0.203716 \\
\hline Prob (F-statistic) & 0.000000 & \multicolumn{2}{|c|}{ Second-Stage SSR } & $1.30 \mathrm{E}+13$ \\
\hline
\end{tabular}

Source: Processed data using Eviews 10 (2019)

2. The effect of GDP and FI on ICI

$I C I_{t}=\beta_{5}+\beta_{6} G D P_{t}+\beta_{7} F I_{t}+e_{t}$

Table 4.2 Second result of Two Stage Least Square

\begin{tabular}{|lrlrr|}
\hline \multicolumn{4}{|l|}{ Dependent Variable: ICI } \\
\hline \multicolumn{4}{|l}{ Method: Panel Two-Stage Least Squares } \\
\hline Variable & Coefficient & Std. Error & t-Statistic & Prob. \\
\hline FI & 0.227431 & 0.048958 & 4.645 .457 & 0.0000 \\
\hline GDP & 0.001430 & 0.000133 & 1.077 .955 & 0.0000 \\
\hline C & 1.094 .073 & 2.059 .686 & 5.311 .841 & 0.0000 \\
\hline R-squared & 0.776727 & Mean dependent var & 3.464 .825 \\
\hline Adjusted R-squared & 0.768893 & S.D. dependent var & 1.737 .597 \\
\hline S.E. of regression & 8.353 .251 & Sum squared resid & 39772773 \\
\hline F-statistic & 9.914 .657 & Durbin-Watson stat & 0.564952 \\
\hline Prob(F-statistic) & 0.000000 & Second-Stage SSR & 39772773 \\
\hline
\end{tabular}

Source: Processed data using Eviews 10 (2019)

The regression result of the Two Stage Least Square (TSLS) method above has mentioned that:

1. $G D P_{t}=-272490.0+469.0190-63.58080+139617.1$

Based on $t$ test (testing individual variables), ICI has a positive and significant effect on alpha $0.01(1 \%)$ of GDP in Indonesia from 2001 to 2018 amounting to 469.0190 and a significance value of 0.0000 . This indicates that if ICI increases by 1 percent, the GDP will increase by 469.0190. The result of the regression is contradictory to the existing theory, because based on research ICI should have a negative effect on GDP.

2. $I C I_{t}=1094.073+0.001430+0.227431+205.9686$

Based on $t$ test (Testing individual variables), GDP has a positive and significant effect on alpha $0.01(1 \%)$ on the ICI from 2001 to 2018 amounting to 0.001430 and the significance level is 0.0000 . this indicates that a 1 percent increase in GDP will be followed by an increase in the ICI 0.001430 . This is in accordance with the theory that states an increase in GDP towards a better direction will increase the selling power of the ICI and attract investors to invest in Indonesia.

3. In this occasion, FI becomes an instrument variable.

Based on t test (individual variable testing) FI, two main variables, namely GDP and ICI, state that FI has a negative effect on GDP and has a positive effect on ICI. The effect of FI in these two variables are with a significance level of $5 \%$ alpha. 


\subsection{Effect of FI and GDP on ICI}

The estimation result of research data indicates that Foreign Investment (FI) has a positive effect on ICI - the higher the level of Foreign Investment is, the higher the value of ICI is. Investors who put their funds in Indonesia make the capital market as a signal whether investment conditions in Indonesia are good or not. This condition is not immediately straightforward, because investment is basically an activity for a fairly long period of time. Therefore, the correlation between FI and ICI is not in the same direction while the estimation result from the GDP variable shows that GDP (Gross Domestic Product) has a positive effect on the ICI. It means that the more the value of GDP increases, the more ICI will increase.

The result of this study is suitable to the research conducted by Setyawan (2009) which states that GDP has a significant positive effect on ICI. Based on the research result, GDP is one of the macroeconomic variables that exist to measure a country's economic growth rate. Rapid GDP growth brings an indication of economic growth in a country. If economic growth improves, the purchasing power of the people increases, and it brings an opportunity for companies to increase their sales and this will raise share prices. Rising stock prices due to GDP will encourage an increase in ICI (Tandelilin, 2007). In addition, an increase in corporate profits can increase investor confidence so that stock prices rise and influence the movement of ICI.

\subsection{Effect of ICI and FI on GDP}

The test result shows a significance level at alpha $1 \%$. It means that ICI has a positive and significant effect on GDP, because GDP growth has an influence on investor expectations so that it affects the movement of stock price indices. This good condition attracts more investors and will certainly expand the scope of economic activity which will ultimately increase economic growth.

TSLS test result between FI and GDP have a negative influence correlation. It is in accordance with the foundation of previous research applied and the basis of this research that states there is a negative and significant influence on economic growth, in the long run - the higher the value of foreign capital investment is, the more economic growth will decline. This occurs because the presence of foreign investment in the long run can slow down economic growth at a position of GDP value, so that a slow decline in the percentage of economic growth occurs in developed countries while in the short term, the influence of foreign investment can create jobs so as to reduce the number of unemployed and increase per capita income and economic growth significantly.

\section{Conclusion}

The result of the research in the first equation explains that FI and GDP have a significant effect on ICI. Partially, FI has a positive influence on ICI. Investment is basically an activity for a long period of time, so that when the Indonesian market signals increase, investors will invest their capital in Indonesia. GDP has a positive influence on ICI. It means that the more the value of GDP increases, the more ICI will increase. Rapid GDP growth brings an indication of economic growth in a country. If economic growth improves, the purchasing power of the people increases, and it brings opportunities for companies to increase their sales and this will raise share prices. Rising stock prices due to GDP will drive up ICI.

The second equation model in this study explains ICI and FI have a significant effect. ICI has a positive correclation towards GDP, while FI has a negative correlation to GDP. The positive correlation between ICI and GDP occurred because GDP growth has an influence on investors' expectations, thereby affecting the movement of stock price index. This good condition attracts more investors and will certainly expand the scope of economic activity which will ultimately increase economic growth. The negative correlation between FI and GDP occurs because the presence of foreign investment in the long run will cause GDP to slow down at a fairly large value.

\section{References}

Indonesiaan Bank. (2019). [Online] Available: https://www.bi.go.id/ (Desember, 2019)

Boediono. (1985). Teori Pertumbuhan Ekonomi. Yogyakarta. BPFE.

Boubakari, Ake, Dehuan Jin. (2010). The Role of Stock Market Development in Economic Growth: Evidence from Some Euronext Countries. International Journal of Financial Research, Vol. 1, No. 1, pg. 14 - 20.

Central Statistics Agency of Indonesian (2019). [Online] Available: https://www.bps.go.id/ (Desember, 2019)

Duca, Gevit. (2007). The Relationship between the Stock Market and the Economy: Experience from International Financial Markets. Bank of Valletta Review, No. 36 pg. $1-12$.

Irawan dan M. Suparmoko. (2002). Ekonomika pembangunan. Yogyakarta. BPFE.

Ishioro, Bernhard O. (2013). Stock Market Development and Economic Growth: Evidence from Zimbabwe. Ekon Misao Praksa DBK. GOD XXII BR. 2 pg. 343 - 360.

Jamil, Poppy C., Devi Kurniawati. (2018). Stock Market and Economic Growth in Indonesia. In the Proceedings of the $4^{\text {th }}$ Asia Future Conference: Peace, Prosperity, and Dynamic Future. The Sekiguchi Global Research Association (SGRA).

Kairupan, David. (2013). Aspek Hukum Penanaman Modal Asing di Indonesia. Jakarta. Kencana Prenadamedia 
Group.

Nieuwerburgh, Stijn Van, Frans Buelens, Ludo Cuyvers. (2006). Stock Market Development and Economic Growth in Belgium. Exploration in Economic History Journal, Vo. 43 pg 13 - 38.

Ngare, Everlyne, Esman Morekwa Nyamongo, and Roseline N. Misati. (2014). Stock Market Development and Economic Growth in Africa. Journal of Economics and Business, Vol. 74 pg. $24-39$.

Pan, Lei, Vinod Mishra. (2018). Stock Market Development and Economic Growth: Empirical Evidence from China. Economic Modelling, No. 68 pg. $661-673$.

Ritter, Jay R. (2005). Economic Growth and Equity Returns. Pacific - Basin Finance Journal, Vol. 13 pg. 489 503.

Setiawan, Adi. (2009). Analisis Pengaruh Faktor Makro Ekonomi, Pangsa Pasar dan Karakteristik Bank Terhadap Profitabilitas Bank Syariah (Studi Pada Bank Syariah Periode 2005-2008), [Online]. Jurnal Bisnis dan Manajemen 2 (3). (Desember 2019).

Sukirno, Sadono. (2004). Makroekonomi: Teori Pengantar. Jakarta. PT. Raja Grafindo Persada.

Sukumar, Nandini. (2017). Preface. In the Role of Stock Exchanges In Fostering Economic Growth and Sustainable Development. United Nations Conference on Trade and Development (UNCTAD) and the World Federation of Exchanges (WFF).

Tandelilin, Eduardus. (2007). Analisis Investasi dan Menejemen. Portofolio (Edisi Pertama Cetakan Kedua). Yogyakarta: BPFE

Todaro, Michael P. (2000). Pembangunan Ekonomi Di Dunia Ketiga. Jakarta. Erlangga.

Widarjono, Agus. (2013). Ekonometrika Pengantar dan Aplikasi. Yogyakarta. YKPN. 